ТАЛЛАЙСКОЕ ЗЕМЛЕТРЯСЕНИЕ 2 сентября 2015 2.

\title{
c $K_{\mathrm{P}}=14.0$, Мw $=5.1, I_{0}=7-8$ на СЕВЕРО-ВОСТОЧНОМ ФЛАНГЕ БАЙКАЛЬСКОГО РИФТА
}

\author{
В.И. Мельникова ${ }^{1,2}$, Н.А. Гилёва ${ }^{2}$, Я.Б. Радзиминович ${ }^{1,2}$, А.И. Филиппова ${ }^{3}$ \\ ${ }^{1}$ Институт земной коры СО РАН, г. Иркутск, vimel@crust.irk.ru \\ ${ }^{2}$ Байкальский филиал ФИЦ ЕГС РАН, г. Иркутск, nagileva@crust.irk.ru \\ ${ }^{3}$ Институт земного магнетизма, ионосферы и распространения радиоволн \\ им. Н.В. Пушкова РАН, г. Москва, г. Tроиџк, ale@crust.irk.ru
}

\begin{abstract}
Аннотация. Рассмотрено Таллайское землетрясение 2 сентября 2015 г. (Mw=5.1), произошедшее в ранее асейсмичном районе Северо-Муйского хребта, примыкающего к Муйско-Куандинской впадине с севера. Приведены инструментальные и макросейсмические данные об этом событии, по амплитудным спектрам поверхностных волн рассчитан тензор сейсмического момента, получены новые сведения о сильных движениях грунта в пределах северо-восточного фланга Байкальского рифта. Установлено, что Таллайское землетрясение связано с сейсмогенным обновлением второстепенных разнонаправленных разрывов, активизация которых произошла в рифтовом поле напряжений.
\end{abstract}

Ключевые слова: землетрясение, инструментальные и макросейсмические данные, тензор сейсмического момента, разломы, Байкальская рифтовая зона.

DOI: $10.35540 / 1818-6254.2021 .24 .29$

Для цитирования: Мельникова В.И., Гилёва Н.А., Радзиминович Я.Б., Филиппова А.И. Таллайское землетрясение 2 сентября 2015 г. с $K_{\mathrm{P}}=14.0, M w=5.1, I_{0}=7-8$ на северо-восточном фланге Байкальского рифта // Землетрясения Северной Евразии. - 2021. - Вып. 24 (2015 г.). - С. 305-313. doi: 10.35540/18186254.2021.24.29

Введение. Территория, отображенная на рис. 1, относится к одному из сейсмически активных сегментов северо-восточной части Байкальской рифтовой зоны (БРЗ). Крупные неотектонические структуры - Северо-Муйский и Южно-Муйский хребты, обрамляющие Муйско-Куандинскую котловину с северо-запада и юго-востока, - в сейсмичности представлены неравномерно. Так, эпицентры относительно сильных землетрясений сосредоточены, главным образом, во впадине и вблизи ее юго-восточного борта. В то же время на северо-западном борту наблюдаются лишь единичные, преимущественно слабые, сейсмические события. Примечательно, что именно на юго-востоке, в районе Муйско-Чарской межвпадинной горной перемычки, произошло крупнейшее в Восточной Сибири Муйское землетрясение 1957 г., $M_{\mathrm{LH}}=7.6[1,2]$ (рис. 1 а).

В контексте сейсмотектонической обстановки особый интерес представляет относительно сильное ощутимое землетрясение 2 сентября 2015 г. ( $M w=5.1)$, произошедшее в ранее асейсмичной области Северо-Муйского хребта (рис. 1 б). По своему местоположению землетрясение названо Таллайским, поскольку его эпицентр локализован в междуречье р. Витим и р. Таллай. Результаты анализа инструментальных и макросейсмических сведений об этом сейсмическом событии приведены в данной статье.

Инструментальные данные. Локализация Таллайского землетрясения была выполнена по данным 36 региональных сейсмических станций (рис. 2) Байкальского, Бурятского, Якутского и Алтае-Саянского филиалов ФИЦ ЕГС РАН, а также Института земной коры (ИЗК) СО РАН. Ближайшей к эпицентру $(\Delta=29 \kappa м)$ оказалась станция «Неляты», пять станций находились на расстояниях до 200 км; на максимальной удалении $(1371 \kappa м)$ располагалась станция «Кунгуртуг».

Основные параметры главного толчка по материалам различных сейсмологических агентств представлены в табл. 1. В целом имеющиеся решения неплохо согласуются между собой: разброс в положении эпицентра не превышает $15 \mathrm{k}$, при этом наименьшие ошибки локации получены в BAGSR, наибольшие - в BJI (см. врезку к рис. 2). 


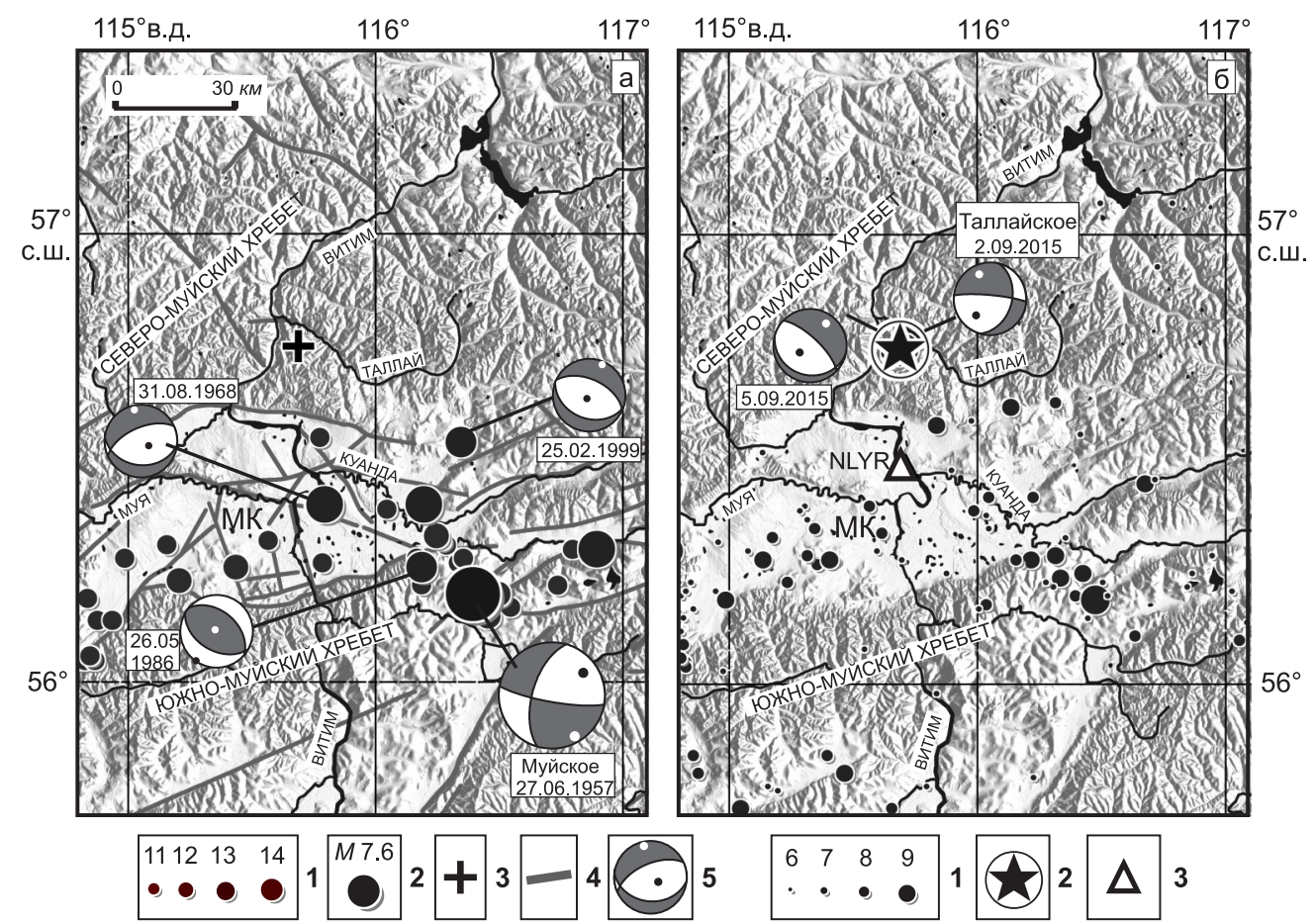

Puc. 1. Схемы эпицентральных полей землетрясений за периоды 1952-2014 гг. (а) и 2015 г. (б)

(a): 1 - эпицентры землетрясений с K户 $=11-14 ; 2$ - эпицентр Муйского землетрясения 27 июня 1957 г. с $M_{\mathrm{LH}}=7.6$ [2]; 3 - крестиком обозначено местоположение эпицентра будущего Таллайского землетрясения $(M w=5.1) ; 4$ - активные разломы по [3]; 5 - стереограмма механизма очага землетрясения в проекции нижней полусферы, выходы осей главных напряжений сжатия и растяжения обозначены черными и белыми точками; (б): 1 - эпицентры землетрясений c KP $\geq 6 ; 2$ - эпицентр Таллайского землетрясения; 3 - ближайшая сейсмическая станция «Неляты» (NLYR); MK - Myйско-Куандинская впадина.

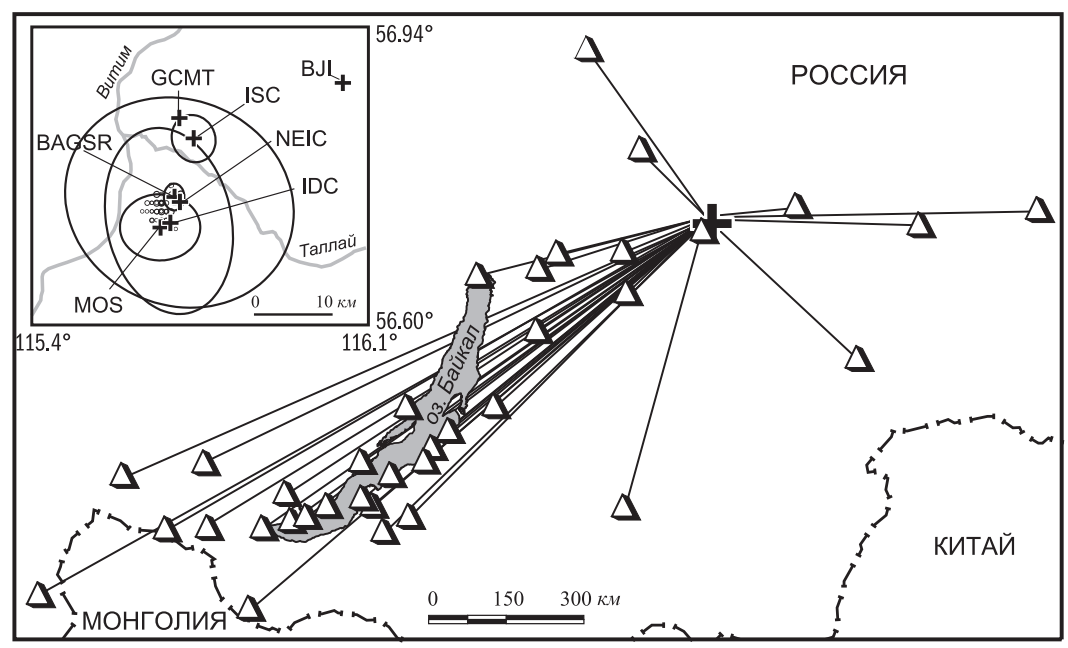

Puc. 2. Положение эпицентра Таллайского землетрясения относительно региональных сейсмических станций, данные которых использовались при обработке материалов наблюдений

На врезке - положение эпицентра главного толчка и эллипсы горизонтальных ошибок по данным разных агентств; кружками показаны эпицентры афтершоков.

Tаблица 1. Основные параметры Таллайского землетрясения по данным различных сейсмологических агентств

\begin{tabular}{|c|c|c|c|c|c|c|c|c|c|c|}
\hline \multirow[b]{2}{*}{$\begin{array}{l}\text { Агент- } \\
\text { ство }\end{array}$} & \multirow[b]{2}{*}{$\begin{array}{c}t_{0}, \\
\text { ч мин с }\end{array}$} & \multirow[b]{2}{*}{$\begin{array}{c}\delta t_{0} \\
c\end{array}$} & \multicolumn{6}{|c|}{ Гипоцентр } & \multirow[b]{2}{*}{ Магнитуда } & \multirow[b]{2}{*}{$\begin{array}{l}\text { Источ- } \\
\text { ник }\end{array}$} \\
\hline & & & $\varphi^{\circ}, \mathrm{N}$ & $\delta \varphi^{\circ}$ & $\lambda^{\circ}, \mathrm{E}$ & $\delta \lambda^{\circ}$ & $\begin{array}{c}h, \\
\kappa M\end{array}$ & $\begin{array}{l}\delta h, \\
\kappa M\end{array}$ & & \\
\hline BAC & .80 & 0.24 & 56.750 & 0.017 & 115 & 0.020 & 11 & 3 & $K_{\mathrm{P}}=$ & {$[4,5,6]$} \\
\hline MOS & $19: 46: 50.50$ & 0.93 & 56.715 & 0.038 & 115.661 & 0.084 & 10 & - & $M S=4.7 / 34, M P S P=5.1 / 28$ & [7] \\
\hline
\end{tabular}


ТАЛЛАЙСКОЕ ЗЕМЛЕТРЯСЕНИЕ 2 сентября 2015 г. с $K_{\mathrm{P}}=14.0, \mathrm{Mw}=5.1, I_{0}=7-8$ на СЕВЕРО-ВОСТОЧНОМ ФЛАНГЕ БАЙКАЛЬСКОГО РИФТА

\begin{tabular}{|c|c|c|c|c|c|c|c|c|c|c|}
\hline \multirow[b]{2}{*}{$\begin{array}{c}\text { Агент- } \\
\text { ство }\end{array}$} & \multirow[b]{2}{*}{$\begin{array}{c}t_{0} \\
\text { ч мин с }\end{array}$} & \multirow[b]{2}{*}{$\begin{array}{c}\delta t_{0} \\
c\end{array}$} & \multicolumn{6}{|c|}{ Гипоцентр } & \multirow[b]{2}{*}{ Магнитуда } & \multirow{2}{*}{$\begin{array}{c}\text { Источ- } \\
\text { ник }\end{array}$} \\
\hline & & & $\varphi^{\circ}, \mathrm{N}$ & $\delta \varphi^{\circ}$ & $\lambda^{\circ}, \mathrm{E}$ & $\delta \lambda^{\circ}$ & $\begin{array}{c}h, \\
\kappa M\end{array}$ & $\begin{array}{l}\delta h, \\
\kappa M\end{array}$ & & \\
\hline NEIC & $19: 46: 52.35$ & 1.39 & 56.744 & 0.106 & 115.701 & 0.220 & $10 \mathrm{f}$ & - & $m_{\mathrm{b}}=4.9 / 255$ & [8] \\
\hline IDC & $19: 46: 50.51$ & 0.41 & 56.720 & 0.098 & 115.681 & 0.129 & Of & - & $m_{\mathrm{b}}=4.5 / 25, M s=4.3 / 46$ & [8] \\
\hline GCMT & $19: 46: 52.30$ & 0.20 & 56.840 & - & 115.700 & - & 21.3 & 0.8 & $M w=5.0 / 122$ & [8] \\
\hline$\overline{\text { ISC }}$ & $19: 46: 51.90$ & 0.47 & 56.817 & 0.025 & 115.730 & 0.040 & $\begin{array}{l}7.3 \\
7.0\end{array}$ & 2.76 & $M s=4.6 / 79, m_{\mathrm{b}}=4.8 / 234$ & [8] \\
\hline$\overline{\mathrm{BJI}}$ & $19: 46: 48.60$ & - & 56.880 & - & 116.040 & - & 11 & - & $m_{\mathrm{b}}=4.7 / 69, M s=5.3 / 68$ & [8] \\
\hline
\end{tabular}

Примечание. Расшифровка кодов агентств дана в Обозначениях к наст. выпуску журнала; $\mathrm{f}-$ фиксированная глубина; * - глубина по $p P$; через слэш обозначено количество используемых станций.

Рассматриваемое землетрясение произошло в слабосейсмичной зоне, где за весь период инструментальных наблюдений не было зарегистрировано ни одного события с $K_{\mathrm{p}}>10$ (рис. 1 a). Следует отметить, что после главного толчка наблюдались немногочисленные афтершоки $\left(N_{\text {aфт }}=37\right)$ низких энергетических классов (табл. 2), которые продолжались менее трех месяцев [9]. Эпицентры афтершоков распределены по площади довольно компактно (см. врезку к рис. 2), при этом ошибки их определения в большинстве случаев не превысили 3 км. Информация о глубинах гипоцентров, благодаря наблюдениям близкой станции «Неляты», была получена для 26 афтершоков. Пик распределения гипоцентров наблюдался на глубине $h=11 \pm 5 \kappa M$.

Tаблица 2. Распределение числа землетрясений Таллайской последовательности по энергетическим классам $K_{\mathrm{P}}$ за период 2.09-26.11.2015 г.

\begin{tabular}{c|c|c|c|c|c|c|c|c}
\hline \multirow{2}{*}{ Период времени } & \multicolumn{5}{|c|}{$K_{\mathrm{P}}$} & \multirow{2}{*}{$N_{\Sigma}$} \\
\cline { 2 - 9 } & 6 & 7 & 8 & 9 & 10 & 14 & \\
\hline \hline $2.09-26.11 .2015$ & 17 & 13 & 5 & 1 & 1 & 1 & 38 \\
\hline
\end{tabular}

Для Таллайского землетрясения по записям поверхностных волн и дополнительной информации о знаках первых вступлений $P$-волн на региональных станциях был определен тензор сейсмического момента (ТСM). Получены следующие данные: скалярный сейсмический момент $M_{0}=0.50 \cdot 10^{17} H \cdot M$, моментная магнитуда $M w=5.1$, глубина гипоцентра $h=8 \mathrm{~km}$ и механизм очага, характеризующийся сдвиго-сбросовыми смещениями по плоскостям разрывов субширотного и субмеридионального простираний (рис. 1 б) (подробная информация о полученном решении приведена в [6]). Определение фокального механизма афтершока (5 сентября 2015 г. с $K_{\mathrm{P}}=10.3$ ) Таллайского землетрясения, полученное по знакам первых вступлений $P$-волн, показало, что в плоскостях разрывов северо-западного простирания в очаге реализуются чисто сбросовые смещения [10].

Тектоническая позиция очага. Эпицентральная область Таллайского землетрясения приурочена к локальному блоку земной коры, расположенному в привитимской части юго-восточных отрогов Северо-Муйского хребта, прилегающих к северному борту Муйско-Куандинской котловины. Эти две крупные тектонические структуры характеризуются разнонаправленными движениями и разделены мощным субширотным разломом древнего заложения. Палеосейсмологические данные свидетельствуют о том, что в течение голоцена здесь происходили сильнейшие землетрясения с $M \geq 7.0$ [11], хотя в современной сейсмичности зона разлома почти не выражена, за исключением единичных толчков в его восточной части (рис. $1 \mathrm{a}$, б).

Наибольшая интенсивность современных тектонических движений в рассматриваемом районе наблюдается во впадине и, частично, в ее юго-восточном горном обрамлении, что выражается в повышенной сейсмической активности наиболее протяженных и четко выраженных внутривпадинных разрывов различного простирания. Как видно из рис. 1 a, ориентация плоскостей разрывов в очагах относительно сильных землетрясений с известными механизмами здесь также различна. В большинстве случаев сейсмогенные дислокации исследуемой территории характеризуются сбросами и сбросо-сдвигами $[1,11]$. Этот факт свидетельствует о том, что общий структурный план района формировался под влиянием сейсмотектонического режима субгоризонтального растяжения, ориентированного вкрест простирания неотектонических структур.

Макросейсмические данные. Эпицентр Таллайского землетрясения расположен на северо-восточном фланге БРЗ в районе с невысокой плотностью населения. Населенные пункты, 
где данное событие могло бы ощущаться, сосредоточены главным образом вдоль трассы Байкало-Амурской магистрали (БАМ) к востоку и западу от эпицентра. К северу и югу от эпицентральной зоны расположены обширные, практически не населенные пространства. В этой связи сбор макросейсмических данных существенно затруднен, что можно считать типичной ситуацией для северо-восточного фланга БРЗ. В случае Таллайского землетрясения информация была получена в основном посредством рассылки опросных листов, а также предоставлена сотрудниками сейсмических станций региональной сети. Кроме того, часть данных была собрана с использованием интерактивной анкеты, размещенной на интернет-сайте БФ ФИЦ ЕГС РАН [12].

Наибольшая наблюденная интенсивность сотрясений, оцениваемая в 6 баллов по шкале MSK-64 [13], зарегистрирована в $c$. Нелятыл. Село, расположенное на правом берегу р. Витим, застроено деревянными одноэтажными домами, весьма устойчивыми к сейсмическим воздействиям. Реакция зданий сводится к сильному сотрясению, осыпанию чешуек побелки, а также возникновению трещин в печах. Наиболее распространенные макросейсмические проявления определяются дребезжанием посуды, окон, дверей и стекол в шкафах; отмечено сильное раскачивание висячих предметов, колебание жидкости в посуде, смещение неустойчивых предметов, скрип, дрожание и раскачивание мебели, хлопанье незапертых створок и дверей. Очевидцы характеризуют событие как волнообразные колебания; люди испытывали сильный испуг и покидали помещения. На открытом воздухе замечено раскачивание деревьев. При землетрясении отмечено беспокойство домашних животных (выли собаки). Был слышен сильный подземный гул, похожий на шум проходящего железнодорожного состава.

Интенсивность сотрясений, оцениваемая в 4-5 баллов, зафиксирована на эпицентральных расстояниях от 32 до $240 \mathrm{kм}$. В пос. Усть-Муя и пос. Муя, расположенных на расстоянии от 32 до 38 км, отмечено сильное сотрясение зданий в целом, скрип полов и стен, дребезжание посуды и оконных стекол. В пгт Таксимо $(\Delta=67 \mathrm{~km})$ в пятиэтажных жилых домах наблюдалось раскачивание висячих предметов (люстры), дребезжание посуды, скрип, дрожание и тряска мебели. Отчетливо ощущались сотрясения зданий, колебания полов, потолков и стен.

Макросейсмические эффекты такой же интенсивности зафиксированы в намного более удаленных населенных пунктах, расположенных к северу от эпицентра в пределах Сибирской платформы на расстояниях от 152 до $240 \mathrm{~km}$. В г. Бодайбо землетрясение ощущало большинство жителей; некоторые очевидцы испытывали испуг, однако в основном реакция была сравнительно спокойной. Ощущалось общее сотрясение зданий, при этом, по свидетельству очевидцев, дрожание было сильнее, чем вызываемое проходящей рядом тяжелой техникой; скрипели полы и потолки. В помещениях дребезжали посуда и оконные стекла; колебалась мебель («шкаф стучал о стену», «диван дрожал»); хлопали незапертые створки и двери; в отдельных случаях незакрепленные предметы сдвигались со своих мест. Сходные эффекты землетрясения отмечены в расположенном поблизости пос. Мамакан. Реакция очевидцев землетрясения сводится в основном к пробуждению спящих и, во многих случаях, к испугу. В помещениях наблюдалось дребезжание посуды, раскачивание висячих предметов, колебание жидкости в посуде, скрип и колебание мебели, хлопанье незапертых створок и дверей; падение неустойчивых предметов, сдвиг картин на стенах. Отмечены случаи беспокойного поведения домашних животных: «попугайчики метались по клетке», «собака во время землетрясения металась по квартире и скулила». В пос. Кропоткин во время землетрясения отмечено пробуждение спящих; очевидцы испытывали испуг. В помещениях скрипели полы и потолки, дребезжала посуда и оконные стекла, дрожала и скрипела мебель, самопроизвольно двигались двери в шкафу-купе, незакрепленные предметы сдвигались с места. Отмечены случаи падения вещей с полок.

Наиболее удаленным от эпицентра населенным пунктом, в котором зафиксированы 4-5балльные макросейсмические эффекты, является пгт Мама $(\Delta=240$ км). Согласно свидетельству очевидцев, в помещении «на втором этаже панельного здания звенела посуда, стекла окон, двигалась мебель, плескалась вода в бутылке». Прочие наблюдавшиеся эффекты включали скрип полов и потолков, смещение и падение незакрепленных предметов, дрожание мебели, самопроизвольное хлопанье межкомнатных дверей.

С интенсивностью 4 балла Таллайское землетрясение ощущалось на эпицентральных расстояниях от 157 до $258 \mathrm{~km}$. В пгт Новая Чара землетрясение характеризуется как волнообразные колебания; в помещениях отмечено дребезжание посуды и оконных стекол, колебание жидкости в посуде, а также общее сотрясение зданий. Реакцию очевидцев можно определить как спокойную, без испуга и паники. В поселках Балахнинский, Луговский, Артемовский, Согдиондон и Горно-Чуйский, расположенных в северных румбах от эпицентра, сотрясения проявились 
весьма отчетливо и вызвали пробуждение спящих. В качестве наиболее характерных наблюдавшихся эффектов следует отметить дребезжание и звон посуды, остекления мебели, окон и дверей, легкое раскачивание висячих предметов, скрип, дрожание и колебания мебели (стулья, кровати, диваны, шкафы).

В пос. Куанда землетрясение, характеризуемое очевидцами как «дрожание», проявилось в виде дребезжания посуды и оконных стекол. Продолжительность колебаний оценивается приблизительно в 30 секунд. Был слышен подземный гул. Интенсивность сотрясений может быть оценена в 3-4 балла.

Наиболее удаленной от эпицентра точкой, где Таллайское землетрясение было замечено, является г. Чита $(\Delta=541 \mathrm{~km})$. Согласно единичным наблюдениям, волнообразные колебания продолжительностью несколько секунд ощущались на верхних этажах зданий. Интенсивность сотрясений можно оценить в 2 балла по шкале MSK-64.

Оценки интенсивности сотрясений по совокупности всей имеющейся информации сведены в табл. 3; схема макросейсмических проявлений типа «пункты-баллы» представлена на рис. 3.

Tаблица 3. Макросейсмические данные о Таллайском землетрясении

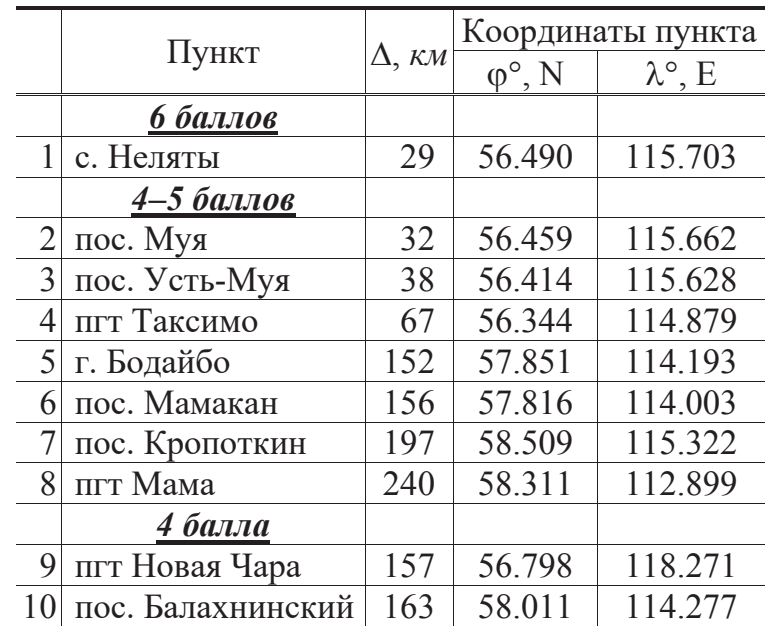

\begin{tabular}{r|l|r|r|r}
11 & пос. Артемовский & 174 & 58.209 & 114.642 \\
\hline 2 & пгт Луговский & 222 & 58.061 & 112.875 \\
\hline 13 & пгт Согдиондон & 237 & 57.694 & 112.160 \\
\hline 14 & пгт Горно-Чуйский & 258 & 57.643 & 111.722 \\
\hline & 3-4 балла & & & \\
\hline 15 & пос. Куанда & 54 & 56.316 & 116.081 \\
\hline & $\quad \underline{\mathbf{2 ~ б а л л а ~}}$ & & & \\
\hline 16 & г. Чита & 541 & 52.033 & 113.550 \\
\hline & Не ощущалось & & & \\
\hline 17 & пос. Перевоз & 260 & 59.002 & 116.920 \\
\hline 18 & пос. Олекма & 307 & 57.024 & 120.731 \\
\hline 19 & пос. Варваринский & 340 & 54.333 & 112.367 \\
\hline 20 & с. Верхняя Заимка & 356 & 55.849 & 110.141 \\
\hline 21 & с. Тунгокочен & 357 & 53.533 & 115.617 \\
\hline 22 & г. Северобайкальск & 411 & 55.636 & 109.336 \\
\hline
\end{tabular}

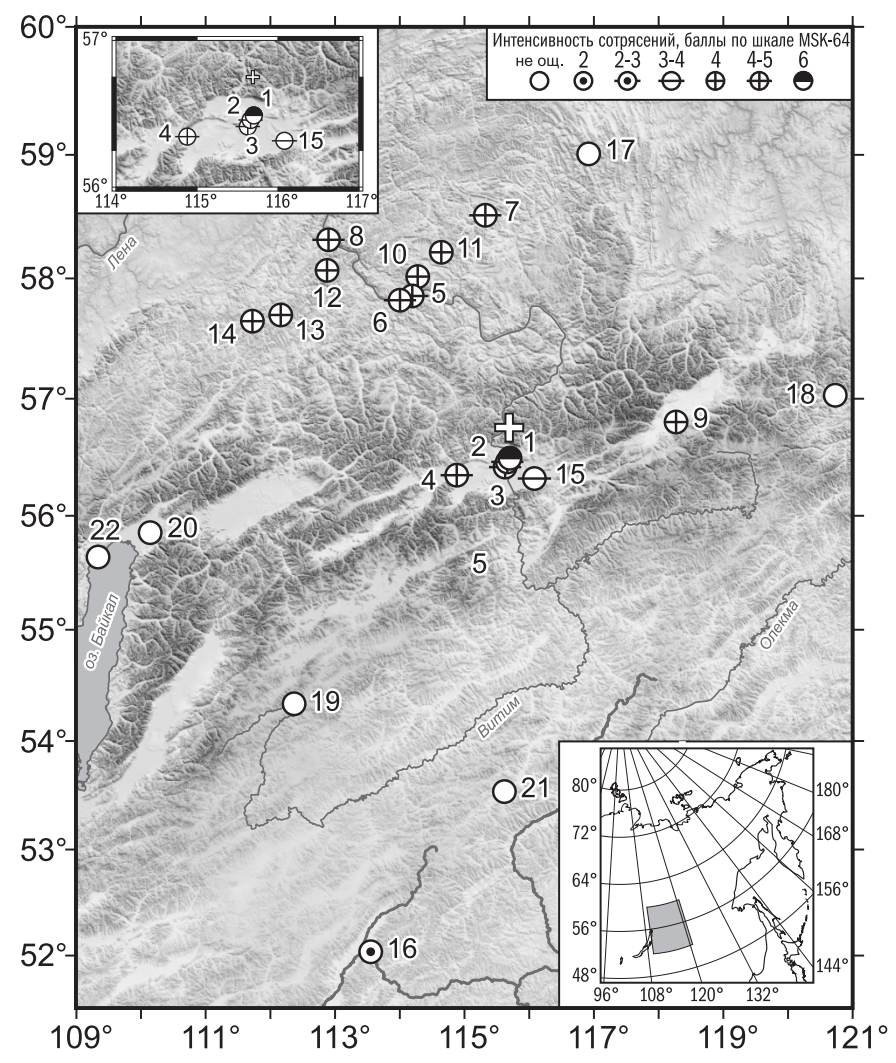

Puc. 3. Карта макросейсмических проявлений Таллайского землетрясения

Крестиком обозначен инструментальный эпицентр. Номера пунктов соответствуют таковым в табл. 3. На врезке серым цветом обозначено положение района исследования на Азиатском континенте.

Сильные движения. Таллайское землетрясение позволило получить новые данные о сильных движениях грунта в пределах северо-восточного фланга БРЗ. Особый интерес представляет запись сейсмической станции «Неляты», расположенной сравнительно близко от эпицентра на расстоянии $\Delta=29 \kappa \mu$ (рис. 4). Максимальная амплитуда ускорений, зарегистрированная на этой станции, составила $A_{\max }=15.9 \mathrm{~cm} / \mathrm{c}^{2}$. Как следует из инструментального раздела шкалы MMSK-92 [14], такое значение $A_{\max }$ соответствует 5-балльным макросейсмическим проявлениям. Инструментальная оценка оказалась несколько 
ниже по сравнению со значением интенсивности, установленным по наблюденным макросейсмическим эффектам в $c$. Неляты (I=6 баллов). Подобное расхождение между оценками, полученными разными способами, в целом можно признать сравнительно небольшим. Более заметное несоответствие оценок по инструментальным и макросейсмическим данным отмечается для сейсмической станции «Бодайбо». Зарегистрированная максимальная амплитуда ускорений $A_{\max }=2.7 \mathrm{~cm} / \mathrm{c}^{2}$ позволяет оценить интенсивность сотрясений лишь в 3 балла, в то время как наблюденные макросейсмические эффекты в пос. Мамакан (пункт фактического местоположения сейсмической станции «Бодайбо») соответствуют интенсивности сотрясений $I=4-5$ баллов. Повышенная наблюденная интенсивность сотрясений в пос. Мамакан и г. Бодайбо по сравнению с ожидаемыми по инструментальным данным значениями неоднократно отмечалась и ранее. Таким образом, наряду с г. Читой район г. Бодайбо и пос. Мамакан также выглядит своего рода аномалией в аспекте более сильной реакции на сейсмические воздействия от землетрясений с эпицентрами на северо-восточном фланге БРЗ. Следует указать на то, что фактическая интенсивность сотрясений в г. Чите ( $I=2$ балла) в данном случае хорошо соотносится со значением максимальной амплитуды ускорений $A_{\max }=0.7 \mathrm{~cm} / \mathrm{c}^{2}$, инструментально зарегистрированным на сейсмической станции «Чита».
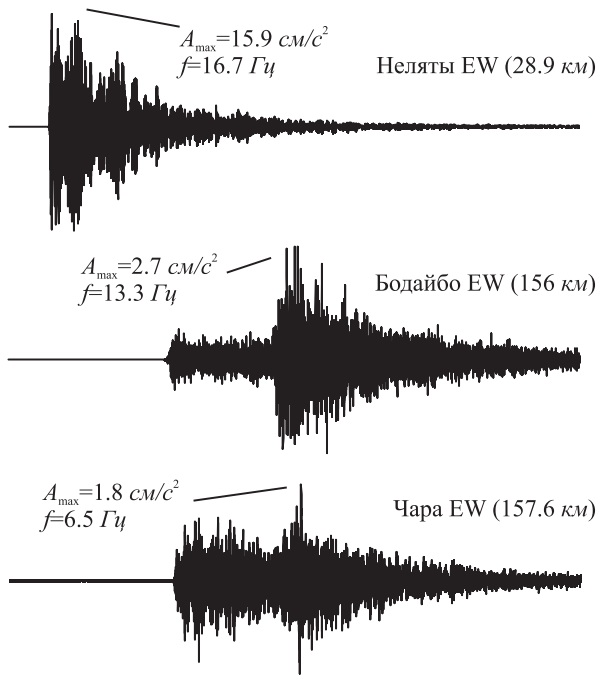

$19^{\mathrm{h}} 47^{\mathrm{m}} 00^{\mathrm{s}} \quad 47^{\mathrm{m}} 30^{\mathrm{s}} \quad 48^{\mathrm{m}} 00^{\mathrm{s}} \quad 48^{\mathrm{m}} 30^{\mathrm{s}}$

Puc. 4. Акселерограммы Таллайского землетрясения, полученные на ближайших к эпицентру сейсмических станциях Байкальского филиала ФИЦ ЕГС РАН

Обсуждение. В районе Таллайского землетрясения присутствуют разломы субмеридионального и северо-западного простирания невысокого ранга, а также и субширотные дизъюнктивы [3]. Разнонаправленные структурные нарушения находят свое отражение в простираниях плоскостей разрывов в очагах главного толчка и его сильного афтершока (рис. 1 а). Следует отметить, что в геодинамической схеме развития северо-восточного фланга БРЗ кинематика крупных разломов, находящихся под действием поперечных сил растяжения, чаще всего характеризуется горизонтальными левосдвиговыми смещениями [15]. В очаге Таллайского землетрясения, как и в очаге сильнейшего Муйского события 1957 г., локализованного на юге Муйско-Куандинской впадины, по субвертикальной широтной плоскости также реализуются левые сдвиги (рис. 1 a, б). Это свидетельствует о том, что разрядка напряжений в очаге данного сейсмического события происходит в полном соответствии с установленными ранее закономерностями напряженно-деформированного состояния земной коры северо-восточной части БРЗ [16].

Макросейсмическое поле Таллайского землетрясения характеризуется ярко выраженной асимметричностью. В частности, следует отметить довольно быстрое затухание интенсивности сотрясений в юго-западном направлении. Об этом свидетельствует отсутствие какой-либо информации об ощутимых эффектах в населенных пунктах, а также на сейсмических станциях региональной сети, расположенных в южных и западных румбах от эпицентральной зоны. Исключением является 2. Чита, расположенный к югу от эпицентра на расстоянии $541 \kappa \mathrm{k}$, где землетрясение все же ощущалось с интенсивностью 2 балла. Этот факт следует рассматривать скорее как аномалию, поскольку согласно расчетам по региональному макросейсмическому уравнению, ощутимые сотрясения в г. Чита вообще не должны были наблюдаться.

Подобной картиной макросейсмических проявлений характеризуются и другие сильные землетрясения северо-восточного фланга БРЗ. Исчерпывающего объяснения подобной неравномерности распределения интенсивности сотрясений на текущий момент не найдено. Возможно, данное явление объясняется сочетанием нескольких факторов сейсмологического, тектонического и инженерно-геологического характера. Свою роль, по-видимому, играет также низкая и неравномерная заселенность этой части Восточной Сибири. Это обстоятельство оказывает существенное влияние на качественные и количественные характеристики макросейсмических данных, что, в свою очередь, часто не позволяет получить детальную картину макросейсмического поля. 
Заключение. Исследование Таллайского землетрясения показало, что данное событие явилось следствием сейсмогенного обновления второстепенных разрывов субширотного, северо-западного и субмеридионального простираний. Активизация этих разнонаправленных дизъюнктивов произошла под влиянием рифтового (субгоризонтального) растяжения, ориентированного в северо-запад-юго-восточном направлении.

Таллайское землетрясение характеризуется неоднородным макросейсмическим полем, типичным для северо-восточного фланга БРЗ. Неравномерное распределение интенсивности сотрясений в пределах рассматриваемой территории может быть обусловлено факторами различного характера, в том числе местными инженерно-геологическими условиями, трудно поддающимися учету в горно-таежной малонаселенной местности. Тем не менее макросейсмические сведения о Таллайском землетрясении, равно как и данные о сильных движениях грунта, могут быть востребованы при проведении работ по уточнению сейсмической опасности зоны БайкалоАмурской магистрали и территории северо-восточного фланга БРЗ в целом.

Работа выполнена при поддержке Минобрнауки России в рамках темы HИР AAAA-A20120060890030-9 госзадания № 075-00576-21 с использованием данных, полученных на уникальной научной установке «Сейсмоинфразвуковой комплекс мониторинга арктической криолитозоны и комплекс непрерывного сейсмического мониторинга Российской Федерации, сопредельных территорий и мира», а также при поддержке РФФИ (проект № 20-05-00823)

\section{Л и т е р а т у р а}

1. Живая тектоника, вулканы и сейсмичность Станового нагорья / Ред. В.П. Солоненко. - М.: Наука, 1966. -224 с.

2. Голенецкий С.И., Хромовских В.С. (отв. сост.); Кисловская В.В., Кондорская Н.В., Солоненко В.П., Шебалин Н.В. V. Прибайкалье // Новый каталог сильных землетрясений на территории СССР с древнейших времен до 1975 г. - М.: Наука, 1977. - С. 315-338.

3. Лунина О.В. Цифровая карта разломов для плиоцен-четвертичного этапа развития земной коры юга Восточной Сибири и сопредельной территории Северной Монголии // Геодинамика и тектонофизика. - 2016. - Т. 7, № 3. - С. 407-434. doi:10.5800/GT-2016-7-3-0215

4. Гилёва Н.А., Хамидулина О.А. (отв. сост.); Меньшикова Ю.А., Дреннова Г.Ф., Курилко Г.В., Емельянова Л.В., Сенотрусова Т.Е., Архипенко Н.С., Павлова Л.В., Терёшина Е.Н., Мазаник Е.В., Инешина М.Ф., Федюшкина Я.И., Папкова А.А., Галактионова Н.Н. Каталог (оригинал) землетрясений Прибайкалья и Забайкалья за 2015 г. с $K_{\mathrm{P}} \geq 3$ (N=36430). - Иркутск: Фонды БФ ФИЦ ЕГС РАН, 2015. - 531 с.

5. Гилёва Н.А., Хамидулина О.А. (отв. сост.); Меньшикова Ю.А., Дреннова Г.Ф., Курилко Г.В., Емельянова Л.В., Сенотрусова Т.Е., Архипенко Н.С., Павлова Л.В., Терёшина Е.Н., Мазаник Е.В., Инешина М.Ф., Федюшкина Я.И., Папкова А.А., Галактионова Н.Н., Филиппова А.И., Радзиминович Я.Б. Каталог землетрясений Прибайкалья и Забайкалья с $K_{\mathrm{P}}>7.5$ за 2015 г. // Землетрясения Северной Евразии. - 2021. Вып. 24 (2015 г.). - [Электронное приложение]. - URL: http://www.ceme.gsras.ru/zse/app-24.html

6. Филиппова А.И., Гилева Н.А. Очаговые параметры сильных землетрясений Прибайкалья и Забайкалья в 2015 г. // Землетрясения Северной Евразии. - 2021. - Вып. 24 (2015 г.). - С. 217-225. doi: $10.35540 / 1818-6254.2021 .24 .21$

7. Сейсмологический бюллетень (сеть телесейсмических станций), 2015. (2021) // ФИЦ ЕГС РАН [сайт]. - URL: ftp://ftp.gsras.ru/pub/Teleseismic_bulletin/2015

8. International Seismological Centre. (2021). On-line Bulletin. https://doi.org/10.31905/D808B830

9. Гилёва Н.А., Хамидулина О.А. (отв. сост.); Меньшикова Ю.А., Дреннова Г.Ф., Курилко Г.В., Емельянова Л.В., Сенотрусова Т.Е., Архипенко Н.С., Павлова Л.В., Терёшина Е.Н., Мазаник Е.В., Инешина М.Ф., Федюшкина Я.И., Папкова А.А., Галактионова Н.Н. Каталог Таллайской последовательности землетрясений с сильным землетрясением 2 сентября 2015 г. с $M w=5.1, K_{\mathrm{P}}=14.0, I_{0}=7-8$ // Землетрясения Северной Евразии. - 2021. - Вып. 24 (2015 г.). - [Электронное приложение]. - URL: http://www.ceme.gsras.ru/zse/app-24.html

10. Мельникова В.И., Гилёва Н.А., Филиппова А.И. (отв. сост.). Каталог механизмов очагов землетрясений Прибайкалья и Забайкалья за 2015 г. // Землетрясения Северной Евразии. - 2021. Вып. 24 (2015 г.). - [Электронное приложение]. - URL: http://www.ceme.gsras.ru/zse/app-24.html

11. Сейсмическое районирование Восточной Сибири и его геолого-геофизические основы / Ред. В.П. Солоненко. - Новосибирск: Наука, СО, 1977. - 303 с. 
12. Радзиминович Я.Б., Хритова М.А., Гилёва Н.А. Современные способы получения макросейсмических данных и возможности их применения на территории Восточной Сибири // Вулканология и сейсмология. - 2014. - № 6. - С. 59-74. doi:10.7868/S0203030614060066

13. Медведев С.В., Шпонхойер В., Карник В. Международная шкала сейсмической интенсивности MSK64. - М.: МГК АН СССР, 1965. - $11 \mathrm{c}$.

14. Шебалин Н.В., Аптикаев Ф.Ф. Развитие шкал типа MSK // Магнитное поле Земли: математические методы описания. Проблемы макросейсмики (Вычислительная сейсмология; Вып. 34). - М.: Геос, 2003. - С. 210-253.

15. Шерман С.И., Леви К.Г. Трансформные разломы Байкальской рифтовой зоны и сейсмичность ее флангов // Тектоника и сейсмичность континентальных рифтовых зон. - М.: Наука, 1978. - С. 7-18.

16. Мельникова В.И., Гилева Н.А., Курушин Р.А., Масальский О.К., Шлаевская Н.С. Выделение условных районов для ежегодных обзоров сейсмичности региона Прибайкалья и Забайкалья // Землетрясения Северной Евразии в 1997 году. - Обнинск: Изд-во ФОП, 2003. - С. 107-117.

\title{
THE SEPTEMBER 2, 2015, $K_{\mathrm{R}}=14.0, M w=5.1, I_{0}=7-8$ TALLAY EARTHQUAKE at the NORTH-EASTERN FLANK of the BAIKAL RIFT \\ V.I. Melnikova ${ }^{1}$, N.A. Gileva ${ }^{2}$, Ya.B. Radziminovich ${ }^{1}$, A.I. Filippova ${ }^{3}$
}

${ }^{1}$ Institute of the Earth's Crust of Siberian Branch of the Russian Academy of Sciences, Irkutsk, vimel@crust.irk.ru ${ }^{2}$ Baikal Branch of Geophysical Survey of the Russian Academy of Sciences, Irkutsk, nagileva@crust.irk.ru ${ }^{3}$ Pushkov Institute of Terrestrial Magnetism, Ionosphere and Radio Wave Propagation of the Russian Academy of Sciences, Moscow, Troitsk, ale@crust.irk.ru

\begin{abstract}
We consider September 2, 2015, $M w=5.1$ Tallay earthquake occurred in the previously aseismic area of the North-Muya Ridge adjoining to the Muya-Kuanda basin from the north. Instrumental and macroseismic data on this seismic event are presented. Its seismic moment tensor is calculated from surface wave amplitude spectra. New data on strong ground motions are obtained within the north-eastern flank of the Baikal rift. The Tallay earthquake is found to be connected with seismogenic renewal of the second-order multidirectional faults activated in the rift stress field.
\end{abstract}

Key words: earthquake, instrumental and macroseismic data, seismic moment tensor, faults, Baikal rift zone.

DOI: $10.35540 / 1818-6254.2021 .24 .29$

For citation: Melnikova, V.I., Gileva, N.A., Radziminovich, Ya.B., \& Filippova, A.I. (2021). [The September 2, 2015, $K_{\mathrm{R}}=14.0, M w=5.1, I_{0}=7-8$ Tallay earthquake at the north-eastern flank of the Baikal rift]. Zemletriaseniia Severnoi Evrazii [Earthquakes in Northern Eurasia], 24(2015), 305-313. (In Russ.). doi: $10.35540 / 1818-6254.2021 .24 .29$

\section{$R$ e f e r e n e s}

1. Solonenko, V.P. (1966). Zhivaya tektonika, vulkany i seismichnost' Stanovogo nagor'ya [Live tectonics, volcanoes and seismicity of the Stanovoy Upland]. Moscow, Russia: Nauka Publ., 224 p. (In Russ.).

2. Golenetsky, S.I., Khromovskikh, V.S., Kislovskaya, V.V., Kondorskaya, N.V., Solonenko, V.P., \& Shebalin, N.V. (1977). [Section V. Baikal]. In Novyy katalog sil'nykh zemletryaseniy na territorii SSSR $s$ drevneyshikh vremen do 1975 goda [A new catalog of strong earthquakes in the USSR from ancient times to 1975] (pp. 315-338). Moscow, Russia: Nauka Publ. (In Russ.).

3. Lunina, O.V. (2016). The digital map of the Pliocene-Quaternary crustal faults in the southern East Siberia and the adjacent Northern Mongolia. Geodynamics \& Tectonophysics, 7(3), 407-434. doi:10.5800/GT-20167-3-0215

4. Gileva, N.A., Hamidulina, O.A., Menshikova, Yu.A., Drennova, G.F., Kurilko, G.V., Emelianova, L.V., Senotrusova, T.E., Arkhipenko, N.S., Pavlova, L.V., Tereshina, E.N., Mazanik, E.V., Ineshina, M.F., Fedyushkina, Ya.I., Papkova, A.A., \& Galaktionova, N.N. (2019). Katalog (original) zemletriasenii Pribaikal'ia i Zabaikal'ia za 2015 gods $K_{\mathrm{R}} \geq 3$ ( $\left.N=36430\right)$ [Catalog (original) of earthquakes of the Pribaikalye and Transbaikalia for 2015 with the $K_{\mathrm{R}} \geq 3(N=36430)$ ]. Irkutsk, Russia: Funds BB GS RAS, 531 p. (In Russ.). 
5. Gileva, N.A., Hamidulina, O.A., Menshikova, Yu.A., Drennova, G.F., Kurilko, G.V., Emelianova, L.V., Senotrusova, T.E., Arkhipenko, N.S., Pavlova, L.V., Tereshina, E.N., Mazanik, E.V., Ineshina, M.F., Fedyushkina, Ya.I., Papkova, A.A., Galaktionova, N.N., Filippova, A.I., \& Radziminovich, Ya.B. (2021). [Cata$\log$ of the earthquakes of the Lake Baykal and Transbaykalia for 2015 with the $K_{\mathrm{R}}>7.5$ ]. Zemletriaseniia Severnoi Evrazii [Earthquakes in Northern Eurasia], 24(2015). Electronic supplement. Retrieved from http://www.ceme.gsras.ru/zse/app-24.html (In Russ.).

6. Filippova, A.I., \& Gileva, N.A. (2021). [Source parameters of strong earthquakes occurred in the Baikal region and Transbaikalia in 2015]. Zemletriaseniia Severnoi Evrazii [Earthquakes in Northern Eurasia], 24(2015), 217-225 (In Russ.). doi: 10.35540/1818-6254.2021.24.21

7. GS RAS, Bulletin of Teleseismic Stations, 2015. (2021). Retrieved from ftp://ftp.gsras.ru/pub/ Teleseismic_bulletin/2015/

8. International Seismological Centre. (2021). On-line Bulletin. https://doi.org/10.31905/D808B830

9. Gileva, N.A., Hamidulina, O.A., Menshikova, Yu.A., Drennova, G.F., Kurilko, G.V., Emelianova, L.V., Senotrusova, T.E., Arkhipenko, N.S., Pavlova, L.V., Tereshina, E.N., Mazanik, E.V., Ineshina, M.F., Fedyushkina, Ya.I., Papkova, A.A., \& Galaktionova, N.N. (2021). [Catalog of the Tallai sequence of earthquakes with strong earthquakes on September 2, 2015 with $\left.M w=5.1, K_{\mathrm{R}}=14.0, I_{0}=7-8\right]$. Zemletriaseniia Severnoi Evrazii [Earthquakes in Northern Eurasia], 24(2015). Electronic supplement. Retrieved from http://www.ceme.gsras.ru/zse/app-24.html (In Russ.).

10. Melnikova, V.I., Gileva, N.A., \& Filippova, A.I. (2021). [Catalog of the focal mechanisms of earthquakes of the Pribaikalye and Transbaikalia for 2015]. Zemletriaseniia Severnoi Evrazii [Earthquakes in Northern Eurasia], 24(2015). Electronic supplement. Retrieved from http://www.ceme.gsras.ru/zse/app-24.html (In Russ.).

11. Solonenko, V.P. (1977). Seismicheskoe raionirovanie Vostochnoy Sibiri i ego geologo-geofizicheskie osnovy [Seismic zoning of Eastern Siberia and its geological and geophysical foundations]. Novosibirsk, Russia: Nauka Publ., 303 p. (In Russ.).

12. Radziminovich, Ya.B., Khritova, M.A., \& Gileva, N.A. (2014). Modern Methods for Acquisition of Macroseismic Data and their Possible Uses for Eastern Siberia. Journal of Volcanology and Seismology, 8(6), 375389. DOI:10.1134/S0742046314060062

13. Medvedev, S.V., Sponheuer, V., \& Karnik, V. (1965). Mezhdunarodnaia shkala seysmicheskoy inten-sivnosti MSK-64 [MSK-64 seismic intensity scale]. Moscow, Russia: MGK Academy of Sciences USSR Publ., 11 p. (In Russ.).

14. Shebalin, N.V., \& Aptikaev, F.F. (2003). [Development of MSK-type scales]. In Magnitnoye pole Zemli: matematicheskiye metody opisaniya. Problemy makroseysmiki (Vychislitel'naya seysmologiya; vypusk 34) [Earth's magnetic field: mathematical methods of description. Problems of macroseismics (Computational seismology; Issue 34)] (pp. 210-253). Moscow, Russia: Geos Publ. (In Russ.).

15. Sherman, S.I., \& Levi, K.G. (1978). [Transform faults of the Baikal rift zone and seismicity of its flanks]. In Tektonika i seismichnost' kontinental'nykh riftovykh zon [Tectonics and seismicity of continental rift zones] (pp. 7-18). Moscow, Russia: Nauka Publ. (In Russ).

16. Melnikova, V.I., Gileva, N.A., Kurushin, R.A., Masalsky, O.K., \& Shlaevskaya, N.S. (2003). [Allocation of conditional areas for annual reviews of seismicity in the Baikal and Transbaikal regions]. In Zemletriaseniia Severnoy Evrazii v 1997 godu [Earthquakes of Northern Eurasia, 1997] (pp. 107-117). Obninsk, Russia: FOP Publ. (In Russ). 